\title{
Game-Based Learning: A Panacea for Better Attitude and Academic Achievement in Basic Science
}

\author{
Ndirika, Maryann Chinwe \\ Department of Science Education, \\ Michael Okpara University of Agriculture, \\ Umudike-Abia State, Nigeria
}

\section{Doi:10.5901/jesr.2013.v3n8p91}

\begin{abstract}
Science is a very potent tool for the development of every nation. Consequently, poor attitude and performance of science students over the years have been a major concern to science educators in Nigeria. This paper reviews the potency of Game-based learning as a tool in enhancing attitude and performance of science students. Research studies reporting poor performance of students and efficacy of game-Based learning are reported. The paper discusses vital aspects of GameBased learning; such as its rules, importance and guidelines. Some examples of useful games in science are given as well as the website for details. Recommendations are made among which is the need to encourage science teachers to use games in science teaching.
\end{abstract}

Keywords: Game, Panacea, Science, Attitude, Achievement

\section{Introduction}

Science is concerned with making discoveries and understanding the environment. It is an intellectual and practical activity, a systematic study of the structure and behaviour of the physical and natural environment, through observation and experimentation. Science presumes that the things and events in the universe occur in consistent patterns that are comprehensible through careful, systematic study. Scientists believe that through the use of the intellect, and with the aid of instruments that extend the senses, people can discover patterns in all of nature.

The reason for inclusion of Science in the school curricula is quite enormous because of the diverse vantage points it places learners as individuals and as members of the society. Among the reasons that can be provided to explain why science is included as a component of Basic Education Curriculum are the following:

- Science helps students to explain events in nature enabling them to identify those beliefs that are superstitious

- Science teaches children how to think and reason in a logical manner

- Science teaches students how to solve simple problems they encounter on a day to day basis.

- Science helps students to develop their physical skills e.g. through the proper handling of objects and equipment e.g. microscope.

- Science enables students to develop their physical skills e.g. establishing friendship while working co-operatively in groups.

- Science helps students to satisfy their natural curiosity through opportunities to carry out scientific investigations.

- Science helps to prepare students for future careers in medicine, pharmacy engineering etc.

- Science helps students to understand, use and control their environment. 
- Science help build a solid foundation for production and employment

- Science brings about improvement in our economy.

- Living is more meaningful with the application of scientific knowledge(National Teachers' Institute,2012)

\section{Students' Attitude and Achievement in Basic Science}

The importance of science and technology in the area of economic and political development of any nation in the world made its teaching to be accorded a lot of importance (Kyle, 1997). On a similar note Okpala (1995) noted that it is necessary for Nigeria, a developing nation, to gear more efforts towards authentic development of science and technology by promoting science teaching and learning in schools.

Various science educationists have shown that students perform poorly in science subjects in Nigeria (Aghadiuno, 1995; Uwadiae, 1997; Farombi, 1998 and Agwagah, 2001). Also, some other researchers (Adeyegbe, 2004; Nwosu, 2000 and Oloruntegbe and Omoifo 2000) reported not only the down ward trend in the achievement in science but also the results getting worse and the recipients getting progressively unscientific in their thought pattern and approach to solving problems.

The poor performance of students in science subjects has been attributed to:

i. Poor quality of science teachers whose methods of teaching-excessive teacher talk, copying of note, note learning of text-books materials tend to inhibit interest

ii. The prevalent expository method of instruction rather than inquiry with very little involvement of students in experimentation

iii. Lack of laboratory facilities and equipment necessary for practical work

Some researchers such as Akinmade (1992), Nwosu and Nzewi, (1998) reported poor professional training, poor academic background of teachers as the main factors for the low performance of students in science subjects. Hillac (2002) said that academic achievement depended most heavily on students' personal conviction of being in charge of their own fate in the learning situation. Kuppuswamy (2002) also noted that an important factor resulting in lower levels of achievement is the fear of failure. He explained that this will haunt some students to the point of where they will not be able to take part in any problem solving test. He further argues that achievement has certain symbolic meanings for the individual, which arouses anxiety and inhibition following it, leading the student/individual to shy away from achievement itself.

In general, the various studies which attempt to explain academic achievement and failure do so beginning with the three elements that intervene in education: parents (family causal factor) teachers (academic casual factors) and students (personal causal factors). Among personal variables most studied are motivation and self-concept. Motivation is considered to be the element that initiates the subjects own involvement in learning: when a student is strongly motivated, all his efforts and personality are directed toward the achievement of specific goals, thus bringing to bear all his or her resources.

According to Gonzalez (1997), a consensus exist among the diverse motivational theories and approaches in as much as they conceptualize motivation in terms of conscious beliefs and values. Other authors have found that students themselves attribute low performance to low ability and to luck (Valle, 1999) and an improvement in performance to motivation (task goal orientation), to selfregulating behaviours and to competence as a function of task characteristics (Slater, 2002).

Of recent Yore, Anderson and Shymansky (2002) aimed to model the relationships of classroom characteristics and students' attributes to students' science achievement. The researchers used hierarchical linear modelling on TIMSS and Science Co-op Local Systemic Change Project data. As results, classroom factors influenced the weightings of significant student attributes, such as, awareness of nature of science, attitude towards science etc Papanastasiou (2002) aimed to investigate the school, teaching and family influence on students' attitudes toward 
science in Cyprus using TIMSS 1995 data and structural equation modelling with LISREL. In the resulting path model, the highest correlation among the latent variables of family, reinforcement, teaching, and climate was the correlation between attitudes and teaching.

Halladyna and Shanghnessy (1982) have concluded that a number of factors have been identified as related to students' attitude to science. Such factors include; teaching methods, teacher's attitude, influence of parents, gender, age, cognitive styles of pupils, career interest, societal view of science and scientists, social implications of science and achievement. Studies have revealed the influence of methods of instruction on students' attitude towards science.

\section{Game-Based Learning}

One of the biggest problems in all formal learning is keeping students motivated enough to stick with the learning process to the end of e.g. a lesson, course, term/semester, Playing Is an important part of children's cognitive and social development A child learns through playing with others, creating, and improving his or her stage of development offers cognitive support needed to develop higher order mental processes, initiates the symbolic use of objects and first form of symbolisation (first step towards abstract thinking)

In a bulletin published by Bern University of Applied Sciences, several elements were highlighted which defines an activity as a game as follows:

- Competition: the score-keeping element and/or winning conditions which motivates the players and provide an assessment of their performances. Note that players are not necessarily competing against each other. In fact a lot of games have players working as a team to overcome some obstacle or opponent built into the game.

- Engagement: Once the learner starts, he or she does not want to stop before the game is overlapped and Cordova (1992) refer to this phenomenon as 'Intrinsic Motivation' and ascribe it to four sources: challenge, curiosity, control and fantasy.

- Immediate Rewards: Players receive victory or points, sometimes even descriptive feedback, as soon as goals are accomplished.

Learning requires efforts, and students rarely do it without motives such as Intrinsic goals, extrinsic rewards, psychological factors; like fear and need to please(Adesoji, 2008).

Play and learning are related. When playing games, students actively see and do, rather than read and listen, as they complete increasingly difficult levels of learning. They are personally involved in what they are doing, and therefore, more motivated to retain what they have learned. The process of learning is often experienced as painful. The process of game-playing is generally engaging. If school activity would be treated in terms of learning, playing, and helping, then children could be more thoroughly engaged in the learning process.

Today's children grow up with computer technology ("Game Generation"). They are capable of processing large amounts of visual, textual, auditory data and demand to be taught in ways that they are comfortable with and not satisfied with traditional learning methods. It is not out of place therefore to conceive and utilise various forms of games especially digital games to impact learning in science classrooms. Computer games offer a programmed environment by which the student can play, experiment, and learn from mistakes and get feedback. Active learning, learning by experience, discovery learning which vital components of learning science are are all achieved through games.

\section{Objectives of Game-Based Learning}

The objectives of Game-based learning include the following:

- To make learning meaningful to students

- To create a learning culture that is more in correspondence to student's interests and learning styles 
- To create learning environments that actively involve students in the problem and enable them to understand the complex situation

- From "learning by listening" to more active "learning by doing"

- To provide a rewarding experience to many people with the application of computer games

\section{Categories of Computer Games}

- Action games

- Platform-jumping games, falling things that must be shot

- Adventure games

- Find the way around the unknown world, solve puzzles

- Simulation games

- Building worlds or companies, flying, driving,

- Fighting games

- Two characters battle each other

- Puzzler games

- Problem solving, presented graphically

- Role-playing games

- To rescue someone, -thing, character can be selected, equipment, action Sport games

- Strategic games(Mayer, 2005)

\section{Importance of Games in Learning Science}

So many positive effects accrue from using games to learn. Some of the benefits of Game-Based learning in science include:

- Games are useful in presenting repetitive learning in normal ways

- Games help in creating awareness, reinforcing facts and knowledge, teaching skills and building values.

- They provide a participatory effect in learning especially in sciences

- Games increase motivation, attention and concentration

- Immerses them in the material so they learn more effectively

- Encourages them to learn from their mistakes

- Enhances tutoring, exploring/practising skills, entertainment and attitude change.

- Computer gaming skills serve as precursor for computer skills.

- Improves problem-solving ability and creativity which are vital components in science learning.

- Support cognitive processing, strategic skills and critical thinking

- Increases learning and memory capabilities

- Accommodates different learning styles

In a study carried out by Papastergiou(2009) to assess the learning effectiveness and motivational appeal of a computer game for learning computer memory concepts, which was designed according to the curricular objectives and the subject matter of the Greek high school Computer Science (CS) curriculum, as compared to a similar application, encompassing identical learning objectives and content but lacking the gaming aspect. The study also investigated potential gender differences in the game's learning effectiveness and motivational appeal. The sample was 88 students, who were randomly assigned to two groups, one of which used the gaming application (Group A, N=47) and the other one the non-gaming one (Group B, N=41). A Computer Memory Knowledge Test (CMKT) was used as the pretest and posttest. Students were also observed during the interventions.

Furthermore, after the interventions, students' views on the application they had used were 
elicited through a feedback questionnaire. Data analyses showed that the gaming approach was both more effective in promoting students' knowledge of computer memory concepts and more motivational than the non-gaming approach. Despite boys' greater involvement with, liking of and experience in computer gaming, and their greater initial computer memory knowledge, the learning gains that boys and girls achieved through the use of the game did not differ significantly, and the game was found to be equally motivational for boys and girls. The results suggest that within high school CS, educational computer games can be exploited as effective and motivational learning environments, regardless of students' gender.

Similarly, a research published by University of Rochester neuroscientists, Shawn Green and Daphne Bavelier suggested that playing "action" video and computer games has the positive effect of enhancing student's visual selective attention.

\section{Guidelines in Using Games to Teach}

The National Teachers Institute (NTI, 2012) in Nigeria stipulated the following guidelines in using games to teach:

- Games should be simple to play

- They should have simple rules

- Competition should not be emphasised

- Skills should be demonstrated

- Related concepts should be clearly illustrated by the game

- Teacher should discuss the main concepts of the game conveyed after the game

- The game should be adapted for the needs of a particular level of pupils

- Assess the value of the game before using it to teach pupils

\section{Examples of Some Games Used in Science Teaching}

There are diverse kinds of games, which a science teacher can use to make science teaching and learning interesting and appealing to science students. Details of these games are available at http://mint.ua.edu/games. Some examples include:

- Simple Machines

- School of elements - Back to school

- Rocks Rock

- Discovering the Periodic Table

- Chemical Connection

- Assay - Mania

- Chemical Mix up etc.

\section{Conclusion}

When games are used in teaching science, students become lively and actively involved in learning. The challenge of the science teacher is thus to meaningfully incorporate them as vital aspects of the lessons in order to make learning fun and to make the games more useful. This paper is just one small part of a very important message that all parents and science educators need to hear which is that Video games, computer games and other games are not to be avoided, but are part of the best opportunities available to engage the present generation students in real and interesting learning, especially in sciences. Game-Based learning could prove useful in addition to traditional teaching, learning methods especially for students, who lack motivation to adopt new attitudes towards learning of science. 


\section{Recommendations}

The following recommendations are made for use of games in learning science:

- Science teachers should be encouraged to incorporate relevant games in science lessons

- Specialists in digital games should be made to create more and easy-to-access websites with details of interesting games on science concepts for use by science teachers and students

- School administrators should invite game professionals to train science teachers on gamebased learning

- Relevant scientific games should be incorporated in the Basic science curriculum and some aspects of continuous assessment based on them

- Adequate number of computers configured with scientific games should be supplied by the federal Government to secondary schools and Basic science students allowed access to them especially at break times.

\section{References}

Adesoji, F.A.(2008). Managing students' attitude towards science through problem - solving instructional strategy Anthropologist, 10(1): 21-24

Adeyegbe, S.O. (2004). Assessment of learning in the West African sub-region: A supplement or an encumberance? Paper presented at the IAEA conference in Philadelphia Pennsylvania.

Aghadiuno, M.C. (1995). A Path Analytic Study of Cognitive Style, Understanding of Science and Attitudinal Variables as Correlates of Achievement in Secondary School Chemistry. Unpublished PhD Thesis, University of Ibadan.

Agwagah, U.N.V. (2001). The Teaching of number bases in junior secondary school mathematics: The use of the base board ABACUS. J ournal of the Mathematical Association of Nigeria Mathematics Education Series, 26(1), 1 - 7.

Akinmade, C.T.O. (1992). Teaching Difficulty in Integrated Science Concept to the Gifted Child. Journal of Science Teachers Association of Nigeria, 27(2), 84-97.

Farombi, J.G. (1998). Resource concentration and management as correlates of students achievement in senior secondary school physics in Oyo state: A study in school quality. An unpublished PhD Thesis, institute of education, University of I badan.

Gonzalez, M.C. (1997). Academic motivation. Its determining factors and guidelines for intervention. Navarra. EUNSA.

Green, S. (2003). Computers in Entertainment (CIE) - Theoretical and practical computer applications in Entertainment Archive 1 (1), 21-22

Halladyna, T. and Shanghnessy, J. (1982 ). Attitudes towards science: A qualitative synthesis. Journal of Research in Science Teaching, 66(4): 547-563.

Hillac, H. (2002). Education in the sub-saharan Africa, Khartoum: Pickerson Press

Kyle, W.C. (1997). The Imperative to improve undergraduate Education in Science, Mathematics and Technology. J ournal of Research in Science Teaching, 34 (6), 557-559.

Mayer, B. (2005). Technology enhanced learning: Psychological foundations and current Trends.css.unigraz.at Retrieved 25th July 2013

Nwosu, A.A. and Nzewi, U.M. (1998). Effective Communication of Integrated Science to Learners. The need for and use of inquiry strategy. STAN 39th Annual Conference Proceedings, (pp 197 - 2000), Ibadan: Heineman.

Nwosu, E.C. (2000). Development, validation and application of a model for assessing teacher effectiveness in secondary school chemistry. Unpublished PhD Thesis, University of Lagos.

Oloruntegbe, K.O. \& Omifo, C.N. (2000). Assessing process skills in STME, going beyond paper and pencil Tests. Educational Thoughts, 1(1), 25-36

Okpala, N.P. (1995). Science and Technology Education for all. In UNESCO (ed) Report on the State of Education in Africa. UNESCO Publications, (pp. 95 - 99). 
Slater, J.N. (2002). Application or motivation theory: an analysis of the motivation of at-risk ninth grade students enrolled in online courses. Dissertation abstracts international section A: Humanities and Social Sciences, 62.

Valle, A.J. (1999). Causl attribution, self concept and motivation in students with high and low academic performance. Revista Espanola de Pedagogia, 214, 525-546

Yore, L. D., Anderson, J. O., \& Shymansky, J. A. (2002). Modeling the Relationships of

Classroom Characteristics and Student Attributes to Students' Science Achievement. Annual Meeting of the National Association for Research in Science Teaching, (New Orleans, LA)

Papanastasiou, C. (2000). Effects of attitudes and beliefs on mathematics achievement. Studies in Educational Evaluation, 26, 27-42

Papastergiou, M. (2009). Digital Game-Based Learning in high school Computer Science education: Impact on educational effectiveness and student motivation Computers and Education 52,(1), 1-12 
